\title{
Infiltration and runoff losses under fallowing and conservation agriculture practices on contrasting soils, Zimbabwe
}

\author{
G Nyamadzawo ${ }^{1,2 *}$, P Nyamugafata ${ }^{2}$, M Wuta $^{2}$, J Nyamangara ${ }^{3}$ and R Chikowo ${ }^{2}$ \\ 'Department of Environmental Science, Bindura University of Science Education, Box 1020 Bindura, Zimbabwe \\ ${ }^{2}$ Department of Soil Science and Agricultural Engineering, University of Zimbabwe, Box MP167, Mount Pleasant, Harare, Zimbabwe \\ ${ }^{3}$ International Centre for Research in the Semi-Arid Tropics (ICRISAT), Matopos Research Station, Box 776, Bulawayo, Zimbabwe
}

\begin{abstract}
Fallowing and conservation agriculture are sustainable farming practices that can be used for soil and water conservation. The objectives of the study were to evaluate the effects of different conservation agriculture practices on rainfall infiltration and soil and water losses across 4 sites, using simulated rainfall. The study was carried out at Domboshawa and the Institute of Agricultural Engineering and Chikwaka smallholder farming areas, 4 sites with different soil types. Conservation agriculture practices evaluated were mulch reaping (MR) and clean reaping (CR) at Domboshawa with $5 \%$ clay and the Institute of Agricultural Engineering (IAE) with 50\% clay. The study also evaluated runoff losses from fallow plots subjected to no tillage (NT) and conventional tillage (CT) at ICRAF Domboshawa site (20\% clay) and fallows subjected to CT in Chikwaka smallholder farming areas ( $4 \%$ clay). Infiltration rates were greater under conservation agriculture practices $\left(>35 \mathrm{~mm} \cdot \mathrm{h}^{-1}\right)$ when compared to CT $\left(<27-29 \mathrm{~mm} \cdot \mathrm{h}^{-1}\right)$. On fallows infiltration rates ranged from $24-35 \mathrm{~mm} \cdot \mathrm{h}^{-1}$ when compared to $<15$ $\mathrm{mm} \cdot \mathrm{h}^{-1}$ in maize under CT. Runoff losses were highest under CT at both Domboshawa and IAE sites, and were 21.5 and $15 \%$ respectively, while there was no runoff under MR and CR. At the ICRAF Domboshawa site, runoff ranged between 0-31\% in fallows and was $57 \%$ in maize under CT. At Chikwaka runoff in CT maize was $58 \%$, while in fallow plots runoff ranged $37-44 \%$. Soil losses ranged from $0.2-0.3 \mathrm{t}^{-h a^{-1}}$ per rainfall event in maize, while in fallows, soil loss ranged from 0-0.1 tha ${ }^{-1}$. The results showed that $\mathrm{CT}$ resulted in reduced infiltration rates, increased soil and water loss when compared to fallowing and conservation agriculture across different range of soils. Conservation agriculture practices and fallowing are potential sustainable cropping practices that reduce soil and water loss and increase water use efficiency.
\end{abstract}

Keywords: Conservation agriculture, fallowing, tillage, rainfall simulations

\section{Introduction}

Soil and water loss is a major challenge in the smallholder farming sector all over the world. In semi-arid Africa, losses of up to $50 \%$ of received rainfall have been reported (Stroosnijder, 2003). In Ethiopia, runoff losses of 39\% (under no till (NT)) to $46 \%$ (under conventional till (CT)) were reported by Welderufael et al. (2008). In South Africa, Hensley et al. (2000) reported runoff losses of between $3.6 \%$ and $29.2 \%$ for conventional-tilled and left bare and no-till, bare flat crusted surface, respectively. In a separate study, Zere et al. (2005) also reported runoff losses of 7 and $29 \%$ for maize under CT and NT bare surface, respectively. High soil losses have been blamed for declining yields and increasing food insecurity among smallholder farmers in most of Sub-Saharan Africa including Zimbabwe (Hernanz, 2002).

In Zimbabwe, several researchers, among them Elwell (1987), Vogel (1992), Moyo (1987) and Munyati (1997), have reported soil losses ranging from 10 to $50 \mathrm{t} \cdot \mathrm{ha}^{-1} \cdot \mathrm{y}^{-1}$, in both low and high rainfall zones. Many researchers studying soil erosion are in agreement that parts of Zimbabwe's smallholder areas face serious erosion problems (e.g. Elwell, 1983; Elwell and Stocking, 1988; Whitlow, 1988). A study by Whitlow and Campbell (1989) reported that over 25\% of the smallholder

\footnotetext{
* To whom all correspondence should be addressed.

面 +263712 752 081; fax: +263271 7534;

e-mail: gnyama@yahoo.com

Received 16 February 2011; accepted in revised form 2 April 2012.
}

areas are severely eroded and this has been cited as the major cause of poor yields (Hernanz, 2002). The same sentiments were also expressed by Elwell (1983), who stated that if soil erosion was not checked immediately by a dynamic policy based on reliable technical information, then we will witness mass starvation within our lifetime.

High levels of runoff losses in smallholder farming areas not only limit water availability, but are also an erosion hazard (Rao et al., 1998) and cause nutrient losses. Elwell and Stocking (1988) reported losses of up to $50 \%$ of applied fertilisers in Zimbabwe. High levels of soil and water loss have been attributed to inappropriate tillage practices which have resulted in reduction of soil organic carbon and destruction of soil structure (Mrabet, 2002; Nyamadzawo et al., 2008b; Thierfelder and Wall, 2009).

Most smallholder areas in Zimbabwe are located in low rainfall areas, where the amount of rainfall in recent years has been up to $100 \mathrm{~mm}$ lower than the average rainfall (Zimbabwe, Department of Meteorological Service, 2002). Climate change has become a major threat to the African continent with many local communities already affected and struggling to adapt or cope with its impacts (Scholes et al., 2008). Climate change models have predicted more moderate drying (5 to $15 \%$ per century) over large parts of Botswana and Zimbabwe and the former Transvaal Province of South Africa (Hulme et al., 2001). There is now general scientific agreement that the mean annual temperature over Southern Africa will rise by 2 to $5^{\circ} \mathrm{C}$ by 2050 (IPCC, 2001; 2007). Increasing temperatures will directly affect water availability, through increased evaporation. Thus, there is a need for farmers use land management 
practices that increase water use efficiency by increasing infiltration rates and reducing evaporation (Marongwe et al., 2011)

Conservation agriculture (CA) practices that minimise soil disturbance and which involve the spreading of crop residues on the soil surface are viable options for increasing water use efficiency because they reduce erosion (Giller et al., 2011) and increase water infiltration and storage in soil (Nyagumbo, 2002; Mzezewa and Van Rensburg, 2011). Some of the benefits of CA are immediate, e.g., improved infiltration rates and reduced soil loss (Thierfelder and Wall, 2009). Conservation agriculture also maintains soil aggregation and higher soil organic carbon (SOC) levels when compared with conventional tillage (CT) (Zotarelli et al., 2005; Chivenge et al., 2007; Thierfelder and Wall, 2009; Marongwe et al., 2011).

Improved fallowing is another option which can be used in the smallholder sector of Zimbabwe. In improved fallows, legumes are planted on fallow land for 1 to 2 years to improve soil fertility. The other advantage of fallowing is that it also improves soil physical properties, such as infiltration rates, hydraulic conductivity, and soil porosity (Nyamadzawo et al., 2008a), besides reducing soil and nutrient losses through runoff (Nyamadzawo et al., 2003).

The integration of improved fallowing and conservation tillage can further improve the soil hydraulic properties (Alegre and Rao, 1996; Norwood, 1994), soil water-holding capacity (Nyamadzawo et al., 2008a) and improve organic carbon stocks in soils (Nyamadzawo et al., 2008b). Improved fallows can play an important role in mitigating climate change through carbon sequestration. This study reports results from soil and water conservation research carried out from 2000 to 2004 at different sites across Zimbabwe. The objectives of the study were to evaluate the effects of different conservation agriculture and fallowing practices on infiltration rates and soil and water losses across 4 sites in Zimbabwe with contrasting soils, using simulated rainfall at an intensity of $35 \mathrm{~mm} \cdot \mathrm{h}^{-1}$.

\section{Materials and methods}

\section{Study sites}

Zimbabwe can be divided into 5 main natural regions based on rainfall regime, soil quality and vegetation, among other factors (Vincent and Thomas, 1960). Annual rainfall is highest in Natural Region (NR) I (>1 $\left.000 \mathrm{~mm} \cdot \mathrm{yr}^{-1}\right)$, which covers approximately $2 \%$ of the land area, and is lowest in NR V. Crop production progressively deteriorates from NR I through to NR V (Moyo, 2000; Vincent and Thomas, 1960), mainly as a result of erratic rainfall.

The study was carried at 4 sites: the Institute of Agricultural Engineering (IAE) is in Natural Region IIa and receives an average annual rainfall of $850 \mathrm{~mm}$; Domboshawa ICRAF site, Domboshawa Conservation Tillage (DCT) site and Chikwaka site are in Natural Region (NR) IIb (Fig. 1), and receive an average of $750 \mathrm{~mm}$ of rainfall annually from November to April. Natural Region II comprises $15 \%$ of the country's land area, and is suitable for intensive farming based on crops or livestock production. It accounts for $75-80 \%$ of the area planted to crops in Zimbabwe and is where most of the staple maize crop is grown (FAO, 2006).

Generally, soils in Zimbabwe that are derived from granite are infertile and deficient in nitrogen $(\mathrm{N})$, phosphorus $(\mathrm{P})$ and sulphur (S). About $70 \%$ of Zimbabwe is covered with sandy soils, mostly derived from coarse granite (Thompson and Purves, 1978). Zimbabwe's sandy soils are low in N, P, and S

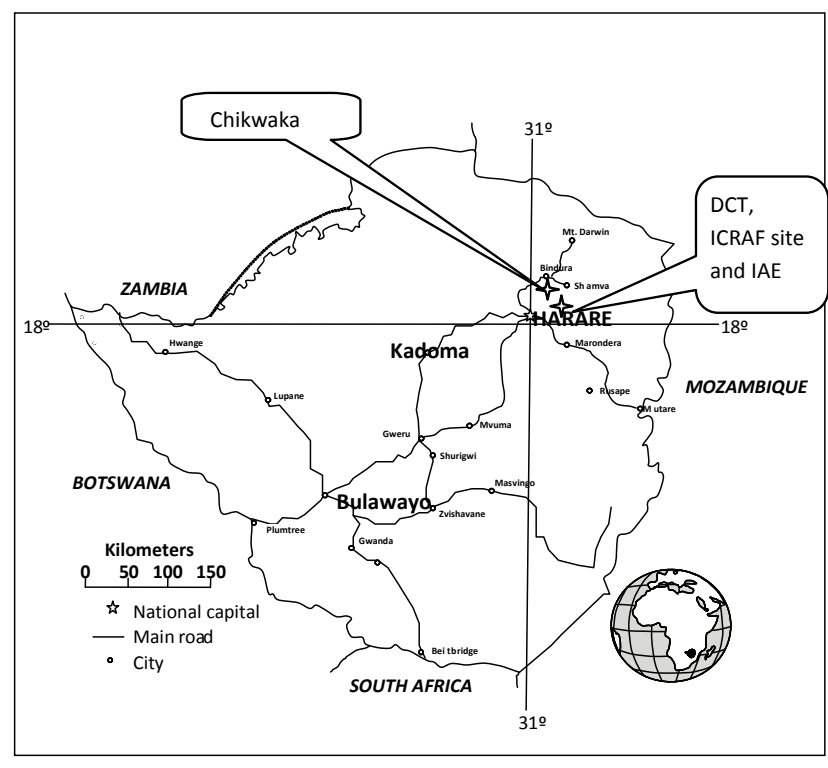

Figure 1

Map of Zimbabwe showing the location of the 4 study sites: Chikwaka, Institute of Agricultural Engineering (IAE), Domboshawa ICRAF site and Domboshawa Conservation Tillage (DCT) sites.

and in cation exchange capacity (CEC), owing to low clay and organic matter contents (Nyamapfene, 1981). As these soils are inherently of low fertility and subject to rapid depletion in fertility, regular applications of organic and inorganic fertilisers are necessary in order to obtain reasonable and sustainable yields. In addition, the sandy soils are generally acidic and require liming.

\section{Domboshawa ICRAF site}

Domboshawa ICRAF site is located at approximately $19^{\circ} 35^{\prime}$ $\mathrm{S}, 31^{\circ} 14^{\prime} \mathrm{E}$, at an altitude of $1474 \mathrm{~m}$. The soils are classified as Lixisols (FAO, 1998). Annual rainfall received during the study period was $750 \mathrm{~mm}$. Figure 1 shows the locations of the study sites and Table 1 summarises soil properties at the study sites. The treatments studied were fallows of Acacia anguistissima (A. anguistissima) and Sesbania sesban (S. sesban); natural fallow (NF) and maize (Zea mays) were the controls.

The experimental layout was a randomised block design and was replicated 3 times. The experiment was initiated in the 1991-92 season, to compare planted fallows of different duration. The different duration fallows were established in a phased manner on $12 \times 9 \mathrm{~m}$ plots, separated from each other by a distance of $2 \mathrm{~m}$. Fallows were established from seedlings. Three-year fallows were first established in 1991-92, two-year fallows in 1992-93, and one-year fallows in 1993-94. The fallow phase was followed by a cropping phase during which all plots were cultivated by ox-drawn plough and planted to maize. After the end of 4 years of cropping, a second 2-year fallow phase was reinstated in the original plots in November 1998 (Table 2). At the end of the fallow period, in October 2000 when the plots were cropped again, the plots were divided into conventional tillage (CT) and no tillage (NT).

Plots were weeded using hoes twice during the growing season and this disturbed the top $0-5 \mathrm{~cm}$ of soil. Fertiliser was applied at the following rates; nitrogen $(\mathrm{N})=60 \mathrm{~kg} \cdot \mathrm{ha}^{-1}$, phosphorus $(\mathrm{P})=15 \mathrm{~kg} \cdot \mathrm{ha}^{-1}$ and potassium $(\mathrm{K})=10 \mathrm{~kg} \cdot \mathrm{ha}^{-1}$. These 


\begin{tabular}{|c|c|c|c|c|c|c|c|c|c|c|}
\hline \multicolumn{11}{|c|}{$\begin{array}{c}\text { Table } 1 \\
\text { Physical and chemical properties of soils sampled from } 0-20 \mathrm{~cm} \text { depth at } \\
\text { Domboshawa ICRAF experimental site, Chikwaka experimental site, Domboshawa } \\
\text { conservation tillage (DCT) site and the Institute of Agricultural Engineering (IAE) site }\end{array}$} \\
\hline & Clay \% & Silt \% & Sand \% & $\begin{array}{c}\mathrm{pH} \\
\left(\mathrm{CaCl}_{2}\right)\end{array}$ & $\begin{array}{c}\text { Organic } \\
\text { C (\%) }\end{array}$ & $\begin{array}{c}\text { Total N } \\
(\%)\end{array}$ & $\begin{array}{c}\operatorname{Resin} P \\
\left(\mathbf{m g} \cdot \mathbf{k g}^{-1}\right)\end{array}$ & $\begin{array}{c}\mathrm{K} \\
(\mathrm{cmol} \\
\left.\mathrm{kg}^{-1}\right)^{c}\end{array}$ & $\begin{array}{c}\mathrm{Ca} \\
\left(\mathrm{mg} \cdot \mathbf{k g}^{-1}\right)\end{array}$ & $\begin{array}{c}\mathrm{Mg} \\
\left(\mathrm{mg} \cdot \mathbf{k g}^{-1}\right)\end{array}$ \\
\hline Domboshawa (ICRAF) site & 22 & 7 & 71 & 4.8 & 0.6 & 0.04 & 3.8 & & & \\
\hline Chikwaka & 4 & 4 & 92 & 4.8 & 0.35 & 0.03 & 5 & 0.09 & 0.83 & 0.37 \\
\hline DCT & 4 & & & & 0.5 & 0.02 & 2 & 0.03 & 1.2 & 1.2 \\
\hline IAE & 59 & 20 & 21 & & 1.1 & & & & & \\
\hline
\end{tabular}

\begin{tabular}{|l|c|c|c|c|c|c|c|c|c|c|c|}
\hline \multicolumn{10}{|c|}{ Table 2 } \\
A timeline showing the management systems that were applied from initial fallow \\
establishment (1992) to October 2001 at Domboshawa ICRAF experimental site \\
\hline \\
\hline
\end{tabular}

were half the generally recommended fertiliser application rates, in order to evaluate if farmers could save on fertiliser costs by using residual fertility from fallows. Compound D fertilizer $(\mathrm{N}=8, \mathrm{P}=6$ and $\mathrm{K}=6)$ was used as a basal application and this was followed by ammonium nitrate $(33.5 \% \mathrm{~N})$, which was applied as split application at knee level and tussling. The maize variety planted was hybrid Seed Company (SC) 513.

\section{Chikwaka smallholder farming area}

The second fallow site was an experimental site that was established on a smallholder farm in Chikwaka (17\% $38^{\prime} \mathrm{S}$, $31^{\circ} 29^{\prime} \mathrm{E}$ ) in December 2000. The site was established in the $2000 / 2001$ season and was a fallow field prior to trial establishment. Soil was sampled from the $0-20 \mathrm{~cm}$ layer, air-dried and chemical compositon analysed (Table 1). The soil was highly leached, coarse-grained sand derived from granite, classified as Arenosols (FAO, 1998) with very low soil organic carbon (SOC) and nitrogen. During the 2000/2001 season, $1100 \mathrm{~mm}$ of rainfall was received, against an annual average of $750 \mathrm{~mm}$.

The experiment was set up to evaluate the potential of improved fallows for improving soil physical properties in comparison to maize under CT. Fallow land was ploughed and subdivided into $10 \mathrm{~m}$ by $12 \mathrm{~m}$ plots. Improved-fallow legumes, Acacia anguistissima, S. sesban, velvet beans (Mucuna pruriens), soyabean and Tephrosia vogeli, were planted in the plots in December 2000. As controls, natural fallow and maize under CT were also included. A complete randomised block design was used and the treatments and controls were replicated 3 times. After a 1-year fallow period, rainfall simulations were carried out in the different plots, in November 2001. Rainfall simulation results for maize, soya bean and Mucuna only are reported in this paper. During the fallowing period soya bean received basal application of $18 \mathrm{~kg} \cdot \mathrm{ha}^{-1} \mathrm{P}$ and $12 \mathrm{~kg} \cdot \mathrm{ha}^{-1} \mathrm{~N}$, in the form of ammonium nitrate, and the seed was inoculated with Rhizobium. After harvesting soya bean seed, the stover and leaf litter were incorporated back into the plots. Mucuna biomass was determined at flowering stage, and sown under in April 2001; no crop was grown in the plots until after the November 2001 rainfall simulations.

\section{Domboshawa Conservation Tillage site}

Domboshawa Conservation Tillage (DCT) site is located at $19^{\circ} 35^{\prime} \mathrm{S}, 31^{\circ} 14^{\prime} \mathrm{E}, 30 \mathrm{~km}$ north of Harare; soils are classified as Arenosols (FAO, 1998). The experiment at Domboshawa was established in the 1988/89 season. The shallow granitederived sands have a clay content lower than $5 \%$; bulk density was $1.6 \mathrm{Mg} \cdot \mathrm{m}^{-3}$ while SOC levels were low (Vogel, 1992; Nyagumbo, 1999), and the land had an average slope of $4.5 \%$. Pedologically, granite-derived sandy soils are typical of many of the communal areas of Zimbabwe (Vogel, 1992). At DCT site the 3 tillage systems, conventional tillage (CT), clean reaping (CR) and mulch reaping (MR), were established in a randomised block design experiment that was replicated 3 times. Each tillage system was based on animal-drawn implements which disturbed the top $15-20 \mathrm{~cm}$. Conventional tillage was carried out by an ox-drawn mouldboard plough in plots where all residues had been removed; under CR all the residues were removed from the plots before reaping, while under MR plots had residues that provided at least $30 \%$ soil cover. Maize was planted continuously as the test crop. Basal fertiliser was applied at a rate of $24 \mathrm{~kg} \cdot \mathrm{ha}^{-1} \mathrm{~N}, 18.5 \mathrm{~kg} \cdot \mathrm{ha}^{-1} \mathrm{P}, 17.5 \mathrm{~kg} \cdot \mathrm{ha}^{-1} \mathrm{~K}$. A split top dressing of ammonium nitrate, providing $138 \mathrm{~kg} \cdot \mathrm{ha}^{-1}$ $\mathrm{N}$, was applied at 5 and 10 weeks after planting (Vogel, 1993), from the 1990/91 season onward.

\section{Institute of Agricultural Engineering (IAE)}

The Institute of Agricultural Engineering (IAE) site ( $17^{\circ} 43^{\prime} \mathrm{S}$; $31^{\circ} 06$ 'E; $1500 \mathrm{~m}$ a.m.s.l.) has deep, well-drained, red clay soil (clay $=59 \%$; silt $=20 \%$; sand $=21 \%$ ) derived from gabbro parent material, classified as Chromic Luvisol (FAO, 1998). The soil had $1.1 \%$ SOC (IAE, 1989) and the average slope was $3 \%$. Experimental design, treatments and test crop at IAE were similar to those at DCT; the main difference between the two sites was soil texture and slope. All treatments received annual fertiliser additions of $114 \mathrm{~kg} \cdot \mathrm{ha}^{-1} \mathrm{~N}, 22 \mathrm{~kg} \cdot \mathrm{ha}^{-1} \mathrm{P}$ and $25 \mathrm{~kg} \cdot \mathrm{ha}^{-1}$ $\mathrm{K}$. Rainfall simulations at DCT and IAE were carried out from August to September, when it was hot and dry, before the start of the rainy season. 


\section{Rainfall simulations}

Rainfall simulations at all 4 sites were conducted at a rainfall intensity of $35 \mathrm{~mm} \cdot \mathrm{h}^{-1}$ on $1 \mathrm{~m}^{2}$ plots which were surrounded by a $50 \mathrm{~cm}$ buffer zone. A portable rainfall simulator based on a single full cone nozzle principle, calibrated after Panini et al. (1993), was used. The plots were demarcated and hydrologically confined using aluminium metal sheets installed on all sides leaving approx. $7 \mathrm{~cm}$ of the sheet above the ground. A metal flume was anchored at the outlet, leading into a small trench to collect runoff. During the simulation events, the soil within the rainfall simulation plots was not disturbed. Rainfall simulations were carried out once in each plot during the dry season (September-October) at all 4 sites. All rainfall simulations involved a dry and wet run, dry runs were conducted on dry soil (5-6\% soil moisture) and wet runs were carried out the following day at the same spot that was used for dry runs.

A container was anchored at the base of the outlet to collect all of the runoff and sediment. Some runoff samples were periodically grabbed to estimate the change in rate of runoff. Runoff was then estimated by summing the runoff collected from the container and that collected during periodic sampling. The sediment collected in the container was weighed before being mixed with the solids separated from runoff collected during the simulations. Solids were separated from water through centrifugation, dried at $60^{\circ} \mathrm{C}$ for $12 \mathrm{~h}$ and weighed. At DCT and IAE soil loss data was not compiled.

However, for DCT and IAE the CR (dry runs) and MR (dry and wet runs) did not produce runoff, thus no steady-state conditions were reached. The same applied to the A. angustissima and natural fallow treatments which did not produce runoff after $30 \mathrm{~min}$ of rainfall simulation. The simulations were limited to $30 \mathrm{~min}$ because this is the normal duration of natural rainfall storms of this intensity. The same rainfall intensity was maintained across sites to enable comparisons of sites.

\section{Data analyses}

For the estimation of infiltration rate, the empirical approach first introduced by Horton (1940) was used. The balance of rain minus runoff estimated infiltration $(I=P-Q)$, where $I$ is the infiltration rate, $P$ is the precipitation and $Q$ is the runoff.
The infiltration data obtained were fitted to a modified version of the Horton-type equation proposed by Morin and Benjamin (1977), given in Eq. (1).

$$
i=i_{f}+\left(i_{o}-i_{f}\right) \mathrm{e}^{-R / K}
$$

where:

$i=$ estimated instantaneous infiltration rate $\left(\mathrm{mm} \cdot \mathrm{h}^{-1}\right) ;$

$i_{f}=$ final infiltration rate $\left(\mathrm{mm} \cdot \mathrm{h}^{-1}\right)$;

$i_{o}=$ initial infiltration rate $\left(\mathrm{mm} \cdot \mathrm{h}^{-1}\right)$;

$R=$ cumulative rainfall ( $\mathrm{mm}$; intensity $\mathrm{x}$ time);

$K=$ infiltration rate decay coefficient which determines the infiltration dynamics or changes in infiltration as affected by soil properties like aggregation, porosity $(\mathrm{mm})$.

Data on time to runoff, amount of runoff and quantity of soil loss were subjected to analysis of variance (ANOVA) using Genstat Statistical package (GENSTAT, 2003).

\section{Results}

\section{Domboshawa ICRAF site}

At Domboshawa ICRAF site the time to runoff was significantly different among treatments $(p<0.05)$. Runoff time was 15-17 min for maize, 21-24 min for $S$. sesban and there was no runoff from $A$. angustissima plots and NF fallow plots as all the rainfall infiltrated. Tillage had no significant effect on time to runoff in all treatments. Runoff losses were significantly higher in maize plots (57\%) when compared to the fallows treatment (Table 3). Maize also had a correspondingly low total rainfall that infiltrated (Fig. 2). Runoff losses in S. sesban averaged $30 \%$ and the final infiltration rates (steady state) were $\sim 24$ $\mathrm{mm} \cdot \mathrm{h}^{-1}$ (Fig. 2), which translated to $12 \mathrm{~mm}$ of water infiltrating in 30 min (Table 3). The total amount of water that infiltrated for $S$. sesban was $60 \%$ greater than for maize under CT.

\section{Chikwaka site}

Time to runoff was comparable for maize and soya bean during dry runs. However, during wet runs, time to runoff for maize was $2 \mathrm{~min}$, when compared to $>4$ min for Mucuna and soya

Table 3

Runoff and soil losses from plots under planted fallows, natural fallow and continuous maize cultivation during $\mathbf{3 0}$ min of simulated rainfall at Domboshawa, Zimbabwe, October 2001

\begin{tabular}{|l|c|c|c|c|}
\hline Treatments & $\begin{array}{c}\text { Time to runoff } \\
\mathbf{( m i n )}\end{array}$ & $\begin{array}{c}\text { Runoff losses } \\
\mathbf{( \% )} \\
\text { October } \mathbf{2 0 0 1}^{* *}\end{array}$ & $\begin{array}{c}\text { Rainfall that } \\
\text { infiltrated } \\
(\mathbf{m m})^{*}\end{array}$ & $\begin{array}{c}\text { Soil loss } \\
\left(\mathbf{t} \cdot \mathbf{h a}^{-1}\right) \text { October } \\
\mathbf{2 0 0 1}^{* *}\end{array}$ \\
\hline Maize CT & 15 & $57^{\mathrm{a}}$ & $7.5^{\mathrm{c}}$ & $0.2^{\mathrm{a}}$ \\
\hline Maize NT & 17 & $57^{\mathrm{a}}$ & $7.5^{\mathrm{c}}$ & $0.2^{\mathrm{a}}$ \\
\hline Acacia angustissima CT & $>30$ & $0^{\mathrm{c}}$ & $17.5^{\mathrm{a}}$ & $0^{\mathrm{c}}$ \\
\hline Acacia angustissima NT & $>30$ & $0^{\mathrm{c}}$ & $17.5_{\mathrm{a}}$ & $0^{\mathrm{c}}$ \\
\hline Sesbania sesban CT & 21 & $31^{\mathrm{b}}$ & $12.1_{\mathrm{b}}$ & $0.1^{\mathrm{b}}$ \\
\hline Sesbania sesban NT & 24 & $29^{\mathrm{b}}$ & $12.0^{\mathrm{b}}$ & $0.1^{\mathrm{b}}$ \\
\hline Natural fallow CT & $>30$ & $0_{c}$ & $17.5^{\mathrm{a}}$ & $0^{\mathrm{c}}$ \\
\hline Natural fallow NT & $>30$ & $0^{\mathrm{c}}$ & $17.5^{\mathrm{a}}$ & $0^{\mathrm{c}}$ \\
\hline
\end{tabular}

$C T=$ conventional tillage, $N T=$ no tillage, tonnes per hectare $\left(t \cdot h a^{-1}\right)$

*infiltration $(\mathrm{mm})$ in $30 \mathrm{~min}$, derived from infiltration rate $\left(\mathrm{mm} \cdot \mathrm{h}^{-1} x\right.$ time $(0.5 \mathrm{~h})$

**Adopted from Nyamadzawo et al. (2003). Initial soil moisture content was $5 \%$.

The same symbols $(a, b$ and $c)$ in the same column show no significant differences, while different symbols show significant differences. 


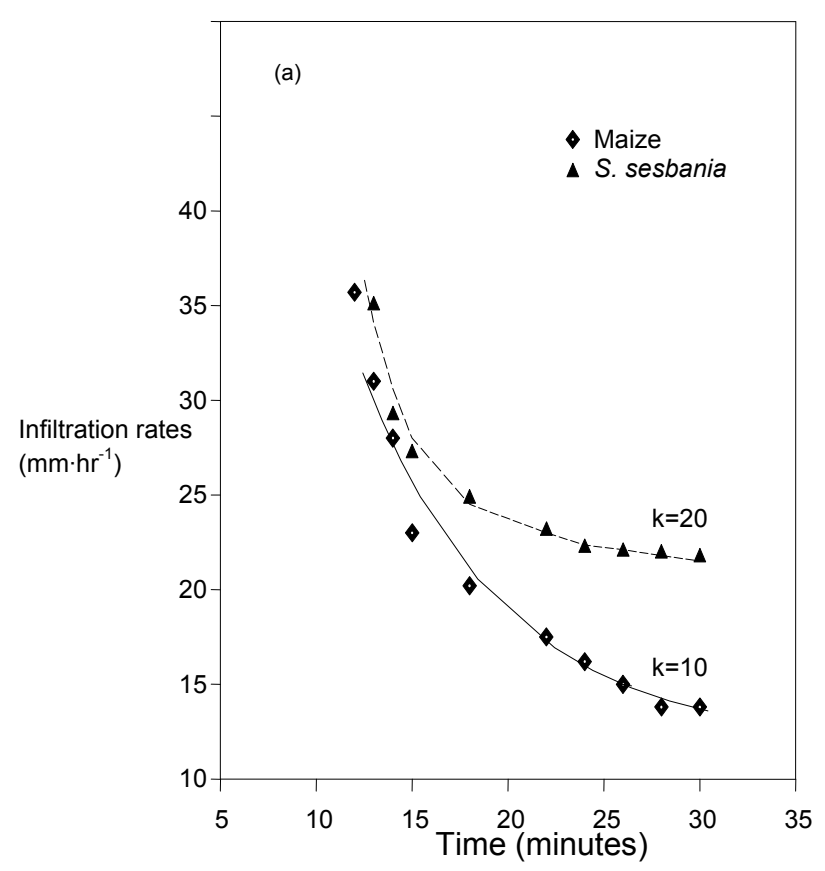

Figure 2

Infiltration rates for Sesbania sesban and continuous maize cultivation plots at Domboshawa ICRAF site in October 2001. Symbols show plotted data and lines show fitted curve using the Morin and Benjamin Model. $K=$ infiltration decay coefficient.

bean. Runoff losses during dry runs were significantly higher $(p<0.05)$ for maize $(58 \%)$, when compared to nil and $15 \%$ for Mucuna and soya bean, respectively. Even during wet runs, maize still had significantly higher runoff losses (64\%) compared to Mucuna $(10 \%)$ and soya bean $(33 \%)$. The amount of rainfall that infiltrated was significantly higher in plots with legumes $(12-15.6 \mathrm{~mm})$ when compared to maize under CT (6-7.4 mm) (Table 4). The amount of rainfall that infiltrated for soya bean was $100 \%$ greater when compared to CT maize during dry runs, while for wet runs the rainfall that infiltrated was 100 and 148\% greater for soya bean and Mucuna, respectively, when compared to CT maize. During dry runs soil losses were not significantly different between soya bean and maize under CT. However, during wet runs soil loss was significantly higher under maize when compared to Mucuna and soya bean. Soil losses were $2.27 \mathrm{t} \cdot \mathrm{ha}^{-1}$ for maize under CT, compared to 1.1 and $1.8 \mathrm{t}^{\mathrm{h}} \mathrm{a}^{-1}$ for Mucuna and soya bean, respectively (Table 4).

\section{Domboshawa Conservation Tillage site}

At DCT, runoff was only obtained from CT plots after 18 min during dry runs and there was no runoff for CR and MR treatment plots. However, during wet runs, the $\mathrm{CR}$ treatment produced runoff after $11 \mathrm{~min}$, while for CT runoff was obtained after only $7.5 \mathrm{~min}$. Conventional tillage had significantly higher $(p<0.05)$ per cent runoff losses $(21 \%)$ for dry runs, compared to no runoff losses under CR and MR. Runoff losses during wet runs were significantly higher $(p<0.05)$ under CT $(65 \%)$, when compared to $23 \%$ under CR and nil under MR (Table 5). Infiltrations were significantly lower under CT, when compared to CR and MR plots (Table 5) for both dry and wet runs. During dry runs $13.8 \mathrm{~mm}$ of the applied rainfall infiltrated under CT compared to $17.5 \mathrm{~mm}$ under CR and MR. However, during wet runs $6.1 \mathrm{~mm}$ of the applied rainfall infiltrated under CT compared to $15.2 \mathrm{~mm}$ under CR and $17.5 \mathrm{~mm}$ under MR. The total rainfall that infiltrated was $150 \%$ greater under CR than $\mathrm{CT}$ plots during wet runs.

\section{IAE Conservation Tillage site}

At the IAE, time to runoff and per cent runoff losses showed the same trend as for DCT. There was no runoff on MR plots for both dry and wet runs. On CR plots, runoff was only obtained during wet runs and on CT plots there was runoff during both dry and wet runs. Runoff losses were significantly higher $(p<0.05)$ under CT when compared to CR and MR.

\begin{tabular}{|c|c|c|c|c|c|c|c|c|}
\hline \multicolumn{9}{|c|}{$\begin{array}{c}\text { Table } 4 \\
\text { Runoff and steady-state infiltration under rainfall simulations at Chikwaka in October } 2001\end{array}$} \\
\hline \multirow[t]{2}{*}{ Treatment } & \multicolumn{2}{|c|}{$\begin{array}{l}\text { Time to runoff } \\
\text { (min) }\end{array}$} & \multicolumn{2}{|c|}{$\begin{array}{c}\text { Runoff losses } \\
(\%)\end{array}$} & \multicolumn{2}{|c|}{$\begin{array}{l}\text { Rainfall that infiltrated } \\
(\mathbf{m m})^{*}\end{array}$} & \multicolumn{2}{|c|}{ Soil loss $\left(\mathrm{t} \cdot \mathrm{ha}^{-1}\right)$} \\
\hline & Dry & Wet & Dry & Wet & Dry & Wet & Dry & Wet \\
\hline cT. maize & 4.5 & 2.0 & $57.7^{\mathrm{a}}$ & $64 \%{ }^{\mathrm{a}}$ & $7.35^{\mathrm{c}}$ & $6.3^{c}$ & $0.31^{\mathrm{b}}$ & $2.27^{\mathrm{a}}$ \\
\hline Mucuna & $>35$ & 4.41 & $0^{\mathrm{c}}$ & $10.3^{c}$ & $17.5^{\mathrm{a}}$ & $15.6^{\mathrm{b}}$ & $0^{\mathrm{c}}$ & $1.05^{\mathrm{c}}$ \\
\hline Sova bean & 5 & 4.05 & $14.9^{b}$ & $31.1^{\mathrm{b}}$ & $14.9^{b}$ & $12.1^{\mathrm{a}}$ & $0.41^{\mathrm{a}}$ & $1.78^{\mathrm{b}}$ \\
\hline
\end{tabular}

C. maize: continuous maize, $n d$ : not determined

* Infiltration $(\mathrm{mm})$ in $30 \mathrm{~min}$, derived from infiltration rate $\left(\mathrm{mm} \cdot \mathrm{h}^{-1} x\right.$ time $(0.5 \mathrm{~h})$.

Soil moisture contents were $4 \%$ for dry runs and $11 \%$ for wet runs.

The same symbols in the same column indicated no significant differences, while different symbols indicate significant differences.

\begin{tabular}{|c|c|c|c|c|c|c|c|c|}
\hline \multicolumn{9}{|c|}{$\begin{array}{c}\text { Table } 5 \\
\text { Time to runoff and runoff loses under rainfall simulations at DCT and October } 2002\end{array}$} \\
\hline Treatment & \multicolumn{2}{|c|}{$\begin{array}{l}\text { Time to runoff } \\
\text { (min) }\end{array}$} & \multicolumn{2}{|c|}{$\begin{array}{c}\text { Runoff losses } \\
\text { (\%) }\end{array}$} & \multicolumn{2}{|c|}{$\begin{array}{l}\text { Rainfall that infiltrated } \\
\qquad(\mathrm{mm})^{*}\end{array}$} & \multicolumn{2}{|c|}{$\begin{array}{c}\begin{array}{c}\text { Soil loss } \\
\left(\mathrm{t} \cdot \mathrm{ha}^{-1}\right)\end{array} \\
\end{array}$} \\
\hline & Dry & Wet & Dry & Wet & Dry & Wet & Dry & Wet \\
\hline MR & $>30.0$ & $>30$ & $0^{\mathrm{b}}$ & $0^{\mathrm{c}}$ & $17.5^{\mathrm{a}}$ & $17.5^{\mathrm{a}}$ & 0 & 0 \\
\hline $\mathrm{CR}$ & $>30.0$ & 11 & $0^{\mathrm{b}}$ & $23^{b}$ & $17.5^{\mathrm{a}}$ & $15.2^{\mathrm{b}}$ & 0 & - \\
\hline CT & 18 & 7.5 & $21^{\mathrm{a}}$ & $65^{\mathrm{a}}$ & $13.8^{\mathrm{b}}$ & $6.1^{c}$ & - & - \\
\hline
\end{tabular}

$C T=$ conventional tillage, $C R=$ clean reaping and $M R=$ mulch reaping.

Initial moisture content was $6 \%$ for dry runs and $12 \%$ for wet runs

*Infiltration ( $\mathrm{mm})$ in $30 \mathrm{~min}$, derived from infiltration rate $\left(\mathrm{mm} \cdot \mathrm{h}^{-1} x\right.$ time $(0.5 \mathrm{~h})$

The same symbols in the same column indicate no significant differences, while different symbols indicate significant differences. 


\begin{tabular}{|l|c|c|c|c|c|c|c|c|}
\hline \multicolumn{8}{|c|}{ Table 6} \\
\hline Treatment & \multicolumn{2}{c|}{$\begin{array}{c}\text { Time to runoff } \\
(\mathbf{m i n})\end{array}$} & \multicolumn{2}{c|}{$\begin{array}{c}\text { Runoff losses } \\
(\%)\end{array}$} & $\begin{array}{c}\text { Water that Infiltrated } \\
(\mathbf{m m})^{*}\end{array}$ & \multicolumn{2}{c|}{ Soil loss (t-ha $\left.{ }^{*}\right)$} \\
\hline & Dry & Wet & Dry & Wet & Dry & Wet & Dry & Wet \\
\hline MR & $>30.0$ & $>30$ & $0^{\mathrm{b}}$ & $0^{\mathrm{b}}$ & $17.5^{\mathrm{a}}$ & $17.5^{\mathrm{a}}$ & 0 & 0 \\
\hline CR & $>30$ & 14 & $0^{\mathrm{b}}$ & $20^{\mathrm{b}}$ & $17.5^{\mathrm{a}}$ & $14.0^{\mathrm{b}}$ & 0 & - \\
\hline CT & 23 & 15 & $15^{\mathrm{a}}$ & $43^{\mathrm{a}}$ & $14.9^{\mathrm{b}}$ & $10.0^{\mathrm{c}}$ & - & - \\
\hline
\end{tabular}

$C T=$ conventional tillage, $C R=$ clean reaping and $M R=$ mulch reaping. Initial soil moisture content was $6 \%$

for dry runs and $14 \%$ for wet runs.

* Infiltration (mm) in $30 \mathrm{~min}$, derived from infiltration rate $\left(\mathrm{mm} \cdot \mathrm{h}^{-1} x\right.$ time $(0.5 \mathrm{~h})$.

The same symbols in the same column indicate no significant differences, while different symbols indicate

significant differences.

Per cent runoff losses were $15 \%$ for CT plots (dry run), $43 \%$ for CT plots (wet run) and 20\% for CR plots (wet run). In MR and CR dry-run infiltration rates were equal or greater than the rate of water supply and therefore there was no runoff on these plots. Infiltration rates were significantly higher $(p<0.05)$ under CR and MR when compared to CT. In CT plots, 14.9 and $10 \mathrm{~mm}$ of the applied rainfall infiltrated when compared to $>35$ and $14 \mathrm{~mm}$ under $\mathrm{CR}$, for dry and wet runs, respectively (Table 6). During wet runs, the rainfall that infiltrated under $C R$ was $40 \%$ greater when compared to CT.

\section{Discussion}

The results across the different fallow systems and tillage systems showed that conventional tillage (CT) resulted in reduced infiltration rates, thus causing greater runoff losses, which supports the findings of earlier research by Elwell and Stocking (1988) and Vogel (1992). In fallow systems, maize had runoff losses of $57 \%$ at Domboshawa ICRAF site and Chikwaka site. There were no significant differences in per cent runoff between NT and CT at the Domboshawa ICRAF site. Sesbania sesban was the only fallow treatment which had runoff at Domboshawa. The total rainfall that infiltrated after 30 min under fallow systems at Domboshawa ICRAF sites was $60 \%$ greater than for CT maize, while at Chikwaka fallows had $100-148 \%$ greater infiltration rates when compared to CT maize after only 1 season of fallowing, showing that CA practices can have immediate benefits of increasing infiltration rates (Thierfelder and Wall, 2009).

At DCT and IAE, runoff losses were highest under CT, and were 21 and $15 \%$, respectively. The total amount of rainfall that infiltrated under CT was 13.8 and $14.9 \mathrm{~mm}$ for DCT and IAE, respectively. The conservation agriculture practice of $\mathrm{CR}$ resulted in 40 and $150 \%$ greater infiltration rates when compared to CT. These results showed that CT resulted in greater runoff losses, which also cause low infiltration rates. Thierfelder and Wall (2009) reported results of similar magnitude; in their study $50 \%$ of the rainfall was lost as runoff under CT compared to $30 \%$ under MR plus legume bean, infiltration rates were $66 \%$ higher and soil moisture was $18 \%$ higher under CA practices than under CT at some sites. With between 15 and $64 \%$ of rainfall received being lost as runoff at the 4 study sites, crops may be affected by moisture stress, as models are predicting a 2 to $5^{\circ} \mathrm{C}$ increase in temperature by 2050 in southern Africa (IPCC, 2007); this will result in reduced plant water availability, and reduced crop yields.

High rates of soil loss have been attributed to $\mathrm{CT}$ using an ox-drawn plough, which destroys soil structure (Thierfelder and Wall, 2009). Conventional tillage weakens soil aggregation because it exposes SOC, which binds soil particles together, to microbial oxidation (Grandy and Robertson, 2006; Thierfelder and Wall, 2009). Traffic during CT pulverises the soil and breaks down soil structure, which can result in clogging of soil pores, surface sealing, reduced infiltration rates and increased runoff and soil erosion (Sumner, 1992). The increase in runoff losses 1 year after fallow termination in fallow treatments at Domboshawa ICRAF site and Chikwaka sites could be attributed to introduction of tillage. The leaf and grass litter that protected the soil surface during fallowing had disappeared through soil incorporation as a result of tillage.

Soil losses were not quantified at all sites; the only available data on soil loss were from sites that were under fallows. At Domboshawa ICRAF site, soil losses were $0.1 \mathrm{t}^{\mathrm{th}} \mathrm{h}^{-1}$ per rainfall event for S. sesban, and $0.2 \mathrm{t}^{-1} \mathrm{a}^{-1}$ for maize. At Chikwaka soil loss was even higher; 0.3 and $0.4 \mathrm{t} \cdot \mathrm{ha}^{-1}$ for maize and soya bean, respectively, per rainfall event during dry runs. However, because of high initial moisture, soil losses were higher during wet runs at Chikwaka site. Although estimates of runoff losses made from small plots such as these cannot readily be extrapolated to the field or landscape scale (Stomph et al., 2002; Van de Giesen et al., 2000), they are indicative of the differences between treatments and management. Elwell and Stocking (1988) reported soil loses of up to $1 \mathrm{t} \cdot \mathrm{ha}^{-1}$ per rainfall event under CT using runoff plots in red clay soils, but this varied depending on rainfall intensities, while Vogel (1992) reported seasonal soil losses of between 10 and $50 \mathrm{t} \cdot \mathrm{ha}^{-1}$ under CT. An 8 -year study by Munyati (1998) found mean annual soil losses of $5.1 \mathrm{t}^{\mathrm{h}} \mathrm{h}^{-1}$, compared to $1 \mathrm{t} \cdot \mathrm{ha}^{-1}$ under MR. These levels of soil losses are very high and unsustainable and can cause reduction of crop yields. Results from both micro-plots and runoff plots indicate that CT causes high soil losses; thus there is need for a shift from the traditional CT to more sustainable cropping practices that reduce soil and water loss and increase water use efficiency (Marongwe et al., 2011).

Conservation agriculture (CA) offers potential benefits to smallholder farmers in Africa. Among the benefits are: avoiding the need for tillage meaning that planting can take place with the first rains; savings on labour and fuel (Smith, 1988) and reduction of soil erosion (Nyagumbo, 2002). Conservation agriculture has the benefit of improving SOC, resulting in less disturbance of the soil and covering the soil surface with plant and leaf residues, all of which conserve the soil (Giller et al., 2011; Vogel, 1992). Benneh et al. (1996) estimated SOC loses of up to $1.1 \mathrm{t} \mathrm{ha}^{-1} \mathrm{yr}^{-1}$ from improved fallows under conservation agriculture systems such as no-tillage (NT), and losses of up to $5.6 \mathrm{t} \mathrm{ha}^{-1} \mathrm{yr}^{-1}$ under conventional (CT) systems. However, 
factors such as soil type, rainfall intensity and amount, and slope, among others, can affect SOC losses. Franzluebbers (2002) reported that greater stratification of SOC under NT than under $\mathrm{CT}$ also reduced soil bulk density by $10 \%$ and improved water infiltration nearly threefold.

The challenges hindering uptake of fallows as a management practice include lack of appropriate knowledge, lack of seedlings, and difficulties in establishing fallows in smallholder farming areas where there is free ranging during the dry season, among other challenges. The challenges to the uptake of conservation agriculture in Zimbabwe include problems of weed control (Anderson and Giller, 2012) and failure by farmers to meet the requirements for use of the technology, such as poor residue retention, lack of labour, lack of knowledge and the inflexible mindset of the farmer. Thus, research and development of CA will need to address these challenges to ensure widespread adaptation (Marongwe et al., 2011) for the benefit of farmers, particularly in marginal areas with low rainfall.

\section{Conclusions}

This study provided an opportunity for a comparison of different management and soil types, given the same rainfall intensity and same duration of rainfall. Comparisons involving the same rainfall intensity are very difficult to achieve with natural rainfall, as intensity varies from place to place. Data from measurements carried out across a range of soils, conservation agriculture practices and fallowing systems at the same rainfall intensity showed that $\mathrm{CT}$ reduced runoff losses and infiltration rates, while conservation agriculture and fallowing reduced soil runoff losses and increased infiltration rates. These findings support those of earlier long-term research. Lower soil losses were also measured for fallows compared to CT. Conservationagriculture practices such as CR, MR, NT and fallowing are possible options for achieving soil and water conservation. Adoption of these technologies in the smallholder farming sector can assist in reducing the loss of rainfall as runoff.

\section{Acknowledgements}

We thank ICRAF, Domboshawa Training Centre and The Institute of Agricultural Engineering for allowing us to use their sites. We are grateful to the European Union for funding the work through the Improved Fallows for Africa (IMPALA) Project No. ICA4-CT 2000-30011.

\section{References}

ALEGRE JC and RAO MR (1996) Soil and water conservation by contour hedging in humid tropics of Peru. Agric. Ecosyst. Environ. 57 17-25.

ANDERSSON JA and GILLER KE (2012) On heretics and God's blanket salesmen: contested claims for Conservation Agriculture and the politics of its promotion in African smallholder farming. In: Sumberg J and Thompson J (eds.) Contested Agronomy: Agricultural Research in a Changing World. Earthscan, London.

BENNEH G, MORGAN WB and UITTO JI (1996) Sustaining the Future. Economic, Social, and Environmental Change in SubSaharan Africa. The United Nations University, United Nations Press, Tokyo.

CHIVENGE PP, MURWIRA HK, GILLER KE, MAPFUMO P and SIX J (2007) Long-term impact of reduced tillage and residue management on soil carbon stabilization: Implications for conservation agriculture on contrasting soils. Soil and Till. Res. 94 328-337.
ELWELL HA (1983) The degrading soil and water resources of the Communal Areas. Zimbabwe Sci. News 17 (9/10) 145-147.

ELWELL H (1987) Modelling sheet erosion and runoff from a fersiallitic clay by combined small-scale physical simulation techniques and field studies. Ph.D. thesis, Department of Soil Science and Agricultural Engineering, Faculty of Agriculture, University of Zimbabwe.

ELWELL H and STOCKING MA (1988) Loss of nutrients by sheet erosion is a major hidden farming cost. Zimbabwe Sci. News 22 (7/8)79-92.

FAO (1998) World Reference Base for Soil Resources. FAO World Soil Resources Reports 84. FAO, Rome. 91 pp.

FAO (2006) Fertiliser Use by Crops in Zimbabwe. Land and Plant Nutrition Management Services, Land and Water Development Division, FAO. FAO, Rome. 68 pp.

FRANZLUEBBERS AJ (2002) Water infiltration and soil structure related to organic matter and its stratification with depth. Soil Till. Res. 66 197-205.

GENSTAT (2003). GENSTAT Statistical Package ( $8^{\text {th }}$ edn.). VSN International, Wageningen.

GILLER KE, CORBEELS M, NYAMANGARA J, TRIOMPHE B, AFFHOLDER F, SCOPEL E and TITTONELL P (2011) A research agenda to explore the role of conservation agriculture in African smallholder farming systems. Field Crops Res. DOI:10.1016/j.fcr.2011.04.010.

GRANDY AS and ROBERTSON GP (2006) Aggregation and organic matter protection following tillage of a previously uncultivated. Soil Sci. Soc. Am. J. 70 1398-1406.

HENSLEY M, ANDERSON JJ, VAN STADEN PP and DU TOIT A (2000) Optimizing rainfall use efficiency for developing farmers with limited access to irrigation water. WRC Report No. 878/1/00. Water Research Commission, Pretoria.

HERNANDEZ JL (2002) Long-term effects of tillage systems and rotations on soil structural stability and organic carbon stratification in semiarid Central Spain. Soil Till. Res. 66 (2) 129-141.

HORTON RE (1940) An approach towards physical interpretation of infiltration capacity. Soil Sci. Soc. Am. Proc. 5 399-417.

INSTITUTE OF AGRICULTURAL ENGINEERING (IAE) (1988-89) Draft Annual Reports of the Institute of Agricultural Engineering, Agritex, Harare, Zimbabwe.

HULME M, DOHERTY R, NGARA T, NEW M and LISTER D (2001) African climate change: 1900-2100. Clim. Res. 17 (2) 145-168.

IPCC (2007) Changes in atmosphere constituents and radiative forcing. In: Solomon S, Qin D, Manning M, Marquis M, Avery K, Miller HL, Chen Z (eds.) Climate Change 2007. The Physical Science Basis: Contribution of Working Group I to the Fourth Assessment Report of the Intergovernmental Panel on Climate Change. Cambridge University Press, New York.

IPCC (2001) Climate change: The scientific basis. In: Houghton JT, Ding Y, Griggs DJ, Noguer M, Van der Linden PJ, Dai X, Maskell $\mathrm{K}$, Johnson CA (eds.) Contribution of Working Group I to the Third Assessment Report of the IPCC. Cambridge University Press, Cambridge.

MARONGWE LS, KWAZIRA K, JENRICH M, THEIFELDER C, KASSAM A and FRIERICH T (2011) An African success: the case study of conservation agriculture in Zimbabwe. Int. J. Agric. Sustainability 9 (1) 1-9.

MORIN J and BENJAMIN Y (1977) Rainfall infiltration into bare soils. Water Resourc. Res. 13 813-817.

MOYO A (1987) The Effects of Soil Erosion on Soil Productivity as Influenced by Tillage: With Special Reference to Clay and Organic Matter Losses Conservation Tillage Project (1988-1997). Institute of Agricultural Engineering, Borrowdale, Harare.

MUNYATI M (1997) Conservation tillage for sustainable crop production: Results and experiences from on-station and on-farm research in Natural Region 2 (1988-1996). Zimbabwe Sci. News 31 27-33.

MZEZEWA J and VAN RENSBURG LD (2011) Effects of tillage on runoff from bare clayey soil on a semi-arid ecotope in the Limpopo Province of South Africa. Water SA 37 (2) 165-172.

NORWOOD C (1994) Profile water distribution and grain yield as affected by cropping systems and tillage. Agron J. 86 558-563. 
NYAGUMBO I (2002) Effects of three tillage systems on seasonal water budget and drainage of two Zimbabwean soils under maize. D.Phil. Thesis, Department of Soil Science and Agricultural Engineering, University of Zimbabwe.

NYAGUMBO I (1999) Conservation tillage for sustainable crop production systems: Experiences from on-station and on-farm research in Zimbabwe (1988-1997). In: Kaumbutho PG and Simalenga TE (eds.) Conservation Tillage with Animal Traction. A resource book of the Animal Traction Network for Eastern and Southern Africa (ATNESA). ATNESA, Harare. 173 pp.

NYAMADZAWO G, NYAMUGAFATA P, CHIKOWO R and GILLER KE (2003) Partitioning of simulated rainfall in a kaolinitic soil under improved fallows. Agrofor. Syst. 59 207-214.

NYAMADZAWO G, NYAMUGAFATA P, CHIKOWO R and GILLER KE (2008a) Residual effects of fallows on infiltration rates and hydraulic conductivities in a kaolinitic soil subjected to conventional tillage (CT) and no tillage (NT). Agrofor. Syst. 72 $161-168$.

NYAMADZAWO G, CHIKOWO R, NYAMUGAFATA P, NYAMANGARA J and GILLER KE (2008b) Soil organic carbon dynamics of improved fallow-maize rotation systems under conventional and no- tillage in Central Zimbabwe. Nutr. Cycl. Agroecosyst. 81 85-93.

NYAMAPFENE KW (1991) Soils of Zimbabwe. Nehanda Publishers, Harare.

PANINI TSM (1993) A portable rainfall simulatorfor rough and smooth morphologies. Quad. Di Sci del Suelo 5 15-19.

RAO KPC, STEENHUIS TS, COGLE AL, SRINIVASAN ST, YULE DF and SMITH GD (1998) Rainfall infiltration and runoff from an Alifisol in semi-arid India. I. No-till systems. Soil Till. Res. 48 51-59.

SCHOLES B, AJAVON A, NYONG T, TABO R, VOGEL C and ANSORGE I (2008) Global Environmental Change (including Climate Change and Adaptation) in Sub-Saharan Africa. ICSU Regional Office for Africa. URL: http://www.icsu-africa.org/docs/ sp gec.pdf (Accessed 8 July 2009).

SMITH RD (1988) Tillage Trials in Zimbabwe 1957 to 1988. Institute of Agricultural Engineering Report, November 1988. Institute of Agricultural Engineering, Harare.

STOMPH T J, DE RIDDER N, STEENHUIS TS and VAN DEGIESEN C (2002) Scale effects on Hortonian overland flow and rainfallrunoff dynamics: Laboratory validation of a process based model. Earth Surf. Proc. Land. 27 847-855.
STROOSNIJDER L (2003) Technologies for improving rain water use efficiency in semi-arid Africa. In: De Villiers M, Mkhize S, Sally $\mathrm{H}$ and Van Rensburg LD (eds.) Proc. Symposium and Workshop on Water Conservation for Sustainable Dryland Agriculture in SubSaharan Africa (WCT), 8-11 April 2003, Bloem Spa Lodge and Conference Centre, Bloemfontein, South Africa. 92-102.

SUMNER ME (1992) The electric double layer and clay dispersion. In: Sumner ME, Stewards BA (eds.) Advances in Soil Science. Soil Crusting, Physical and Chemical Process. Lewis Publishers, Boca Raton. 1-13.

THIERFELDER C and WALL PC (2009) Effects of conservation agriculture techniques on infiltration and soil water content in Zambia and Zimbabwe. Soil Till. Res. 105 217-227.

THOMPSON JG and PURVES WD (1978/81) A guide to the soils of Zimbabwe. Zimbabwe Agricultural Journal Technical Handbook No. 3. Department of Research and Specialist Services, Harare, Zimbabwe.

VAN DE GIESEN NC, STOMPH TJ and DE RIDDER N (2000) Scale effects of Hortonian overland flow and rainfall-runoff dynamics in West African catena landscape. Hydrol. Process. 14 165-175.

VINCEENT V and THOMAS RG (1961) An agro-ecological survey of Southern Rhodesia: Part I Agro-ecological survey. Government Printers, Salisbury.

VOGEL H (1992) Effects of conservation tillage on sheet erosion from sandy soils at two experimental sites in Zimbabwe. Appl. Geogr. 12 229-242.

WHITLOW JR (1988) Land Degradation in Zimbabwe. University of Zimbabwe, Harare.

WHITLOW R and CAMPBELL B (1989) Factors influencing soil erosion in Zimbabwe: a statistical analysis. J. Environ. Anal. 29 (1) $17-29$.

WELDERUFAEL WA, LE ROUX PAL and HENSLEY M (2008) Quantifying rainfall-runoff relationships on the Dera Calcic Fluvic Regosol ecotope in Ethiopia. Agric. Water Manage. 95 1223-1232.

ZERE TB, VAN HUYSSTEEN CW and HENSLEY M (2005) Estimation of runoff at Glen in the Free State Province of South Africa. Water SA 31 (1) 17-22.

ZOTARELLI L, ALVES BJR, URQUIAGA S, TORRES E, DOS SANTOS HP, PAUSTIAN K, BODDEY RM and SIX J (2005) Impact of tillage and crop rotation on aggregate-associated carbon in two Oxisols. Soil Sci. Soc. Am. J. 69 482-491.

ZIMBABWE DEPARTMENT OF METEOROLOGICAL SERVICE (2002) URL: http://weather.utande.co.zw/climate/climatechange. $\underline{\text { htm }}$ (Accessed 17 April, 2012). 